\title{
NEUROPROTECTIVE EFFECT OF MILD HYPOTHERMIA IN THE TEMPORARY BRAIN ISCHEMIA IN CATS
}

\author{
Hiroshi Nakano1, Benedicto Oscar Colli², Luiza da Silva Lopes ${ }^{3}$
}

\begin{abstract}
Objective: To evaluate the neuroprotective effect of mild hypothermia during temporary focal ischemia in cats. Method: 20 cats underwent middle cerebral artery 60 minutes occlusion and 24 hours reperfusion: 10 under normothermia and 10 under mild hypothermia $\left(32^{\circ} \mathrm{C}\right)$. Brain coronal sections $2 \mathrm{~mm}$ thick were stained with 2,3,5-triphenyltetrazolium hydrochloride, photographed and evaluated with software for volume calculation. Results: Cortical ischemia was found in 7 and basal ganglia ischemia in 8 animals of group 1 and in both regions in 5 animals of group 2 (no difference: $p=0.6499$ for cortical; $p=0.3498$ for basal ganglia). No ischemia was found in 5 animals of group 2 and in none of group 1 (significant difference, $p=0.0325)$. The infarct volume was greater in group 1 than $2(p=0.0433)$. Conclusion: Mild hypothermia did not interfere with location of ischemia, but it was effective for reducing the infarct volume.
\end{abstract}

KEY WORDS: cats, focal cerebral ischemia, mild hypothermia, neuroprotection.

\begin{abstract}
Efeito neuroprotetor da hipotermia leve na isquemia cerebral focal temporária em gatos
RESUMO - Objetivo: Avaliar o efeito neuroprotetor da hipotermia leve na isquemia cerebral focal temporária em gatos. Método: Oclusão da artéria cerebral média durante 60 minutos e 24 horas de reperfusão em 10 gatos sob normotermia e 10 sob hipotermia leve $\left(32^{\circ} \mathrm{C}\right)$. Secções cerebrais coronais de $2 \mathrm{~mm}$ coradas com 2,3,5-cloreto de trifeniltetrazolio, fotografadas e cálculos volumétricos (hemisférios/áreas isquêmicas) com programa específico. Resultados: Isquemia cortical em 7 e nos gânglios da base em 8 animais do grupo 1 e em ambas as regiões em 5 animais do grupo 2 (sem diferença: $p=0,6499$ cortical; $p=0,3498$ gânglios da base). Cinco animais do grupo 2 e nenhum do grupo 1 não apresentaram isquemia (diferença significante, $p=0,0325)$. 0 volume do infarto foi maior no grupo $1(p=0,0433)$. Conclusão: Hipotermia leve não interferiu com a localização da isquemia mas foi eficaz para reduzir o volume do infarto.
\end{abstract}

PALAVRAS-CHAVE: gatos, isquemia cerebral focal, hipotermia leve, neuroproteção.

Brain ischemia is common found in arterial vasospasm secondary to subarachnoid hemorrhage, by brain injury and during temporary occlusion of arteries during neurovascular procedures. Despite attempts of using many strategies, the results of treatment for cerebral stroke are not ever satisfactory. The severity of brain lesion depends on the duration of ischemia, on the vessel occluded and on collateral circulation. Several studies aiming better understanding of the ischemia/reperfusion pathophysiology and the improvement of brain protection in these phenomena have been done. In human being, these studies are generally clinical evaluations and image examinations that not allow detection of early cellular phenomena secondary to ischemia/reper- fusion. Experimental models have the advantage of better control of biological variable and allow the use of more accurate methods for measure and evaluation of results. The main disadvantage is the difficult to transpose the findings from the laboratory to human beings.

Among the maneuvers used for brain protection, hypothermia is outstanding. Its mechanism of action is not completely understood, but it should be multifactorial. The effect of deep hypothermia was demonstrated in experimental studies, nevertheless, it is associated with severe side effects ${ }^{1-3}$. Mild to moderated hypothermia has been demonstrated to have neuroprotective effect ${ }^{2,4}$, without severe side effects ${ }^{5}$. The parameters for the best use of the neuroprotec-

Division of Neurosurgery - Department of Surgery and Anatomy - Hospital das Clínicas - Ribeirão Preto Medical School University of São Paulo, Ribeirão Preto SP, Brazil: 'M.D., Ph.D., Assistant Professor of Neurosurgery, Marília Medical School, Marília SP, Brazil; ${ }^{2}$ M.D., Ph.D., Professor of Surgery, Head of the Division of Neurosurgery, Department of Surgery and Anatomy, Ribeirão Preto Medical School, University of São Paulo; ${ }^{3}$ M.D., Ph.D., Assistant Professor, Department of Surgery and Anatomy, Ribeirão Preto Medical School, University of São Paulo.

Received 30 January 2007, received in final form 11 May 2007. Accepted 21 June 2007.

Dr. Benedicto Oscar Colli - Departamento de Cirurgia / HCFMRP - Campus Universitário USP - 14048-900 Ribeirão Preto SP - Brasil. E-mail: bocolli@fmrp.usp.br 
tive effect of the hypothermia in the temporary focal ischemia are not yet well defined, specially the differences among the species. The cat is an adequate model for the study of temporary focal ischemia similar to situations finding in the human being. We did not find studies demonstrating the possible neuroprotective effect of the hypothermia on focal ischemia in cats.

In this study ${ }^{6}$ we intended to evaluate the possible neuroprotective effect of mild hypothermia during temporary focal ischemia in cats.

\section{METHOD}

This study ${ }^{6}$ was approved by the Ethical Committee for Animal Experimentation of the Ribeirão Preto Medical School - University of São Paulo, and followed the policy proposed by the International Council for Laboratory Animal Science, aiming to keep the ethical procedure in all steps of the research.

Twenty normal adult mongrel cats weighing approximately $3 \mathrm{~kg}$ and presumed age ranging from 1-3 years-old, which were allowed free access to food and water before and after all procedures, were used. The animals were randomized in two groups according the body temperature during the ischemia: Group 1 (control) - Ten animals submitted to ischemia with the body temperature at $37^{\circ} \mathrm{C}$ and Group 2 (hypothermia) - Ten animals submitted to ischemia with the body temperature at $32^{\circ} \mathrm{C}$.

Animal preparation and monitoring - Anesthesia was induced with $8 \mathrm{mg} / \mathrm{kg} /$ weight of intramuscular ketamine (Lab. Parke-Davis Ltda., Rio de Janeiro, RJ, Brazil), and maintained during the procedure with $17 \mathrm{mg} / \mathrm{kg} /$ weight of intravenous sodium thiopental (Abbot Laboratórios do Brasil, São Paulo, SP, Brazil), with orotraqueal tube for ventilatory assistance with a KT-600 ventilator (K. Takaoka, Industria e Comércio Ltda., São Paulo, SP, Brazil), with positive pressure. The mean arterial pressure was monitored using a mercury column and a catheter inserted in the right femoral artery. Body temperature was monitored with a rectal thermometer and was maintained with heating from a light source. Hypothermia was induced with an ice bag over the chest/abdomen, starting when before the induction of ischemia. A catheter was inserted in the left femoral vein to obtain blood sample for glucoses dosages, periodic gasometrical analysis and fluid (gluco-saline solution) intake.

Induction of ischemia - Ischemia was induced using a postorbital approach ${ }^{7}$. The animals were placed in a left lateral position and a supra-orbital incision was performed exposing the temporal muscle. This muscle was displaced posteriorly allowing a craniectomy around the optic foramen. The dura-mater was opened along the cranial base under the operating microscope. The intradural optic nerve was identified and the brain was slight shifted for opening the chiasmatic cistern and identification of the right internal carotid artery (ICA) and its branches. The right middle cerebral artery (MCA) was isolated and occluded with a Yas- argil clip (FE 710 - Aesculap, Tuttlingen, Germany), during 1 hour, followed by reperfusion during 24 hours. The animals were sacrificed with massive intravenous dose of sodium thiopental and the brain was removed for analysis.

Morphometry - The brain was removed in a few minutes through a calvariectomy and resection of dura-mater after section of the medulla/spinal cord and of the cranial nerves. The brain were cut in coronal slices 2 millimeters thick using in a cast for cat brain (Matrix - ASI - Instruments - CBM - 2000C, New York, NY, USA), with a microtome blade, and the slices were immersed in a $2 \%$ solution of triphenyltetrazolium hydrochloride (TTC - Sigma-Aldrich, Saint Louis, MO, USA) in normal saline at $37^{\circ} \mathrm{C}$ for $30 \mathrm{~min}$ utes, after which the slices were fixed in $20 \%$ phosphatebuffered formalin. The ischemic areas become evident because of non-staining by TTC. Brain slices were sequentially positioned and photographed with a digital camera, with a ruler for calibration of the morphometric system. Measurements of the images were performed using a software for calculating the slices areas (IMAGE J 1.36, National Institute of Health - USA), and of the WizardPen $4 \times 3$ device [(tablet cordless pen device - Genius KYE Systems America Corporation, Taipei - Taiwan), by an independent observer blinded to the groups. The hemispheres and infarct areas were outlined for better identification. The infarct volume (IV), expressed in cubic millimeters, was calculated to be the sum of the infarct areas on each slice $\left(I_{n}\right)$ multiplied by the distance $(2 \mathrm{~mm})$ between the successive slices $\left(\mathrm{VI}=2\right.$. [ $\mathrm{I}_{1}$ $\left.+\mathrm{I}_{2}+\ldots+\mathrm{I}_{\mathrm{n}}\right]$ ), as proposed by Werstermaier et al. ${ }^{8}$. To correct for brain size or edema, IV were calculated as percentage values of the total volume of the contralateral hemisphere $^{9}$. Localization of the ischemic areas was performed using an atlas of cat brain anatomy ${ }^{10}$.

Statistical analysis - Statistical analysis was performed using the Fisher exact test for comparing incidence and the Mann-Whitney-U test for comparing volumes of ischemic areas. An $\alpha$-error probability not exceeding $5 \%$ was considered significant for two-tailed probability tests. The tests were performed using Graph Pad PRISM (version 3.0; Graph Pad Software Inc. San Diego, CA, USA).

\section{RESULTS}

Some examples of coronal brain slices from animals of groups 1 (control) and 2 (hypothermia) stained with TTC are presented in Figure 1.

Cortical areas were affected with variable frequency and intensity (Table 1). Subcortical areas were more uniformly compromised by the ischemic process (Table 2).

Ischemia involved cortical areas in 7 and basal ganglia in 8 animals of group 1 and cortical areas and basal ganglia in 5 animals of group 2 . There was no significant difference among groups 1 and 2 (exact test of Fisher) in relation to the compromise of cortical areas $(p=0.6499)$ and to the compromise of 


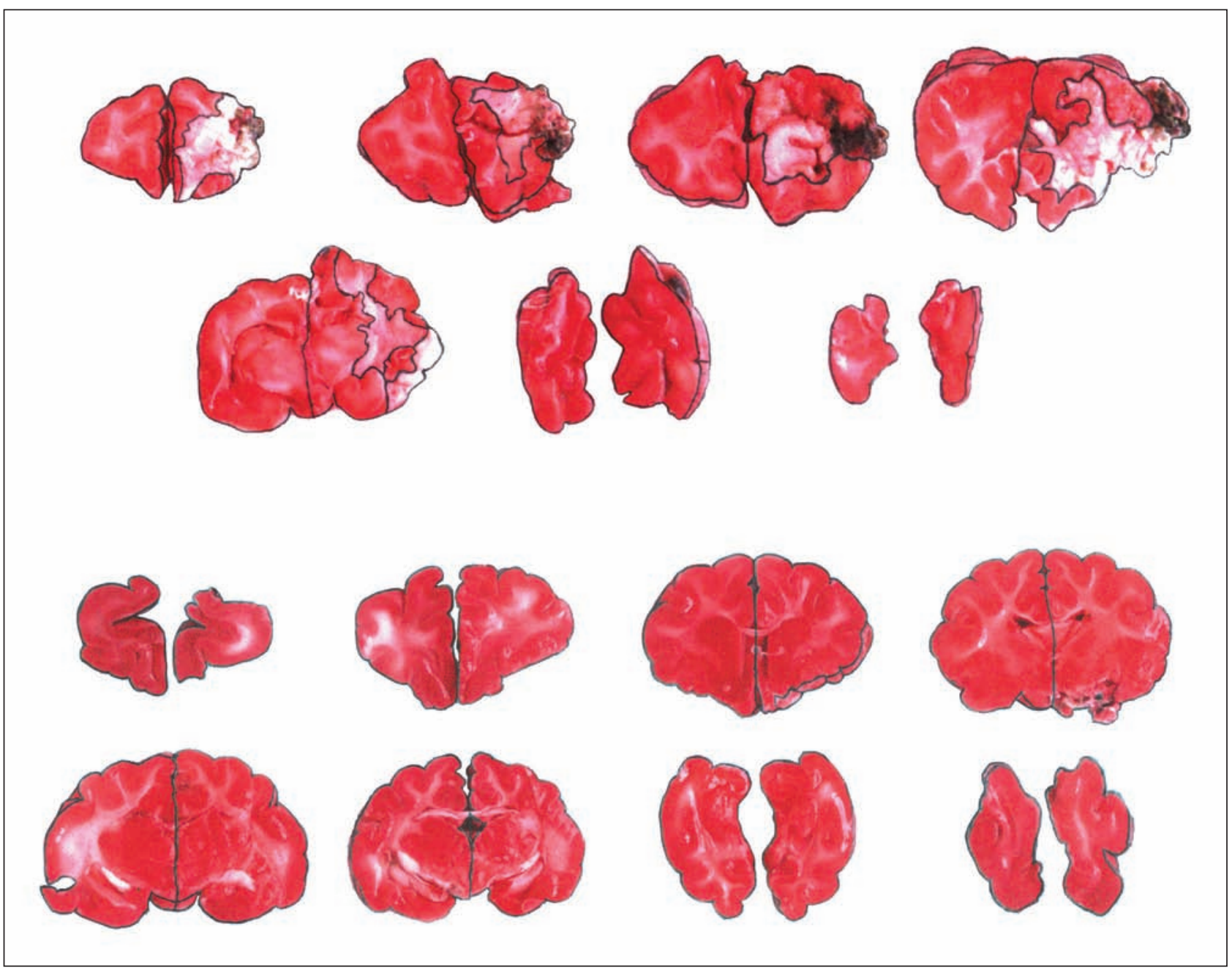

Fig 1. Coronal sections of brain cats underwent focal temporary cerebral ischemia stained with 2,3,5 triphenyltetrazolium. The hemispheres and ischemic areas were outlined for better identification. Upper: animal of group 1 (normothermia)showing extensive areas of ischemia. Bottom: animal of group 2 (hypothermia) showing no ischemic areas.

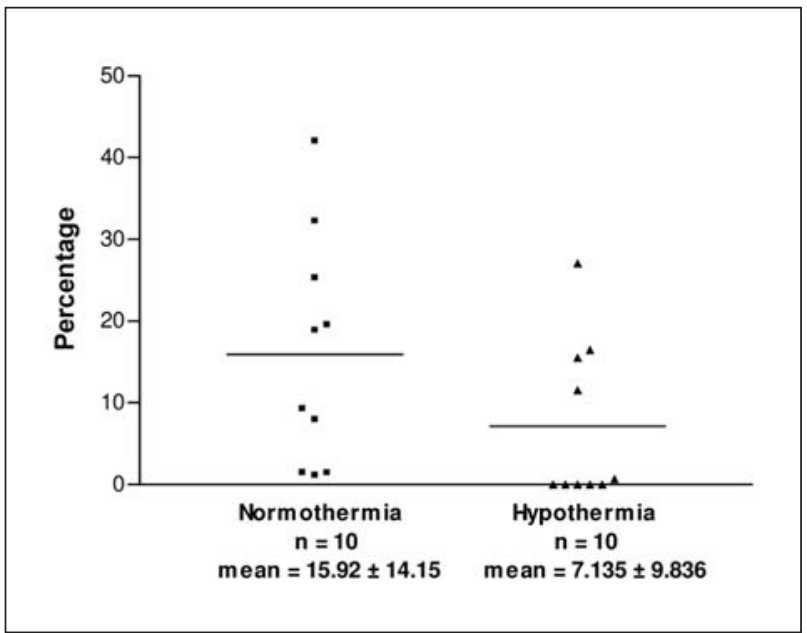

Fig 2. Distribution of percentages of brain ischemic areas in relation to the non-ischemic hemisphere in both experimental groups (significant difference, $P=0.0433$, Mann-Whitney $U$ ). basal ganglia ( $p=0.3498$ ). Five animals of group 2 do not presented signs of ischemia and this fact was not observed among animals of group 1 (significant difference, exact test of Fisher, $p=0.0325$ ).

The distribution of the percentage of ischemic areas in relation to the non-ischemic hemispheres of animals of groups 1 and 2 is presented in Figure 2. There was significant difference between the percentages of the ischemic areas of animals of group 1 and 2 , in favor of animals underwent hypothermia $(p=0.0433$, Mann-Whitney $U)$.

\section{DISCUSSION}

Difficulties to obtain effective treatment of brain ischemia allied to ethical and technical problems and the high cost for observation of ischemic phenomena in human beings have induced researchers to 
Table 1. Cortical areas affected by focal ischemia by temporary occlusion of the middle cerebral artery in normothermic (group 1) and hypothermic (group 2) cats.

\begin{tabular}{cccc} 
Clfactory & $\begin{array}{c}\text { Cortical areas } \\
\text { (Mainly Piriform Area) } 20,22,36,50 \\
\text { and 52 of Brodmann } \\
\text { (Auditory) }\end{array}$ & $\begin{array}{c}\text { Areas } 4 \text { (involved in } \\
\text { all) 4b, 6, and/or 14 of } \\
\text { Brodmann (Motor) }\end{array}$ & $\begin{array}{c}\text { Areas 2, 3 (involved in } \\
\text { all), and/or 43 of } \\
\text { Brodmann } \\
\text { (Somatosensory) }\end{array}$ \\
7 & 7 & 4 & 4 \\
4 & 3 & 3 & 2 \\
\hline
\end{tabular}

Table 2. Subcortical areas affected by focal ischemia by temporary occlusion of the middle cerebral artery in normothermic (group 1) and hypothermic (group 2) cats.

\begin{tabular}{|c|c|c|c|c|c|c|c|c|c|c|c|c|}
\hline & \multicolumn{12}{|c|}{ Subcortical areas } \\
\hline & \multirow{2}{*}{$\begin{array}{l}\text { Nucleus } \\
\text { Caudatus }\end{array}$} & \multirow{2}{*}{$\begin{array}{l}\text { Lateral } \\
\text { Thalamus }\end{array}$} & \multirow{2}{*}{$\begin{array}{l}\text { Globu } \\
\text { Pallidum }\end{array}$} & \multirow{2}{*}{ Putamen } & \multirow[t]{2}{*}{ Claustrum } & \multicolumn{3}{|c|}{ Capsulas } & \multirow{2}{*}{$\begin{array}{l}\text { Centum } \\
\text { Semivale }\end{array}$} & \multirow{2}{*}{$\begin{array}{l}\text { Corona } \\
\text { Radiata }\end{array}$} & \multirow{2}{*}{$\begin{array}{l}\text { Coliculus } \\
\text { Striatum }\end{array}$} & \multirow{2}{*}{$\begin{array}{c}\text { Comissura } \\
\text { Anterior }\end{array}$} \\
\hline & & & & & & Interna & Externa & Extrema & & & & \\
\hline $\begin{array}{l}\text { Normothermic } \\
\text { group }\end{array}$ & 7 & 4 & 5 & 4 & 4 & 6 & 5 & 5 & 4 & 4 & 7 & 7 \\
\hline $\begin{array}{l}\text { Hypothermic } \\
\text { group }\end{array}$ & 5 & 2 & 2 & 3 & 3 & 3 & 4 & 2 & 2 & 2 & 2 & 2 \\
\hline
\end{tabular}

get more knowledge about this changes in laboratorial experiments. Cats has some advantages as an animal for experiments such as its medium size, ease to be anesthetized, to be kept under controlled ventilation, and to keep physiological parameter under anesthesia, besides could be an interesting model for temporary focal cerebral ischemia. As disadvantages, the used cats were captured and it was not ease to keep them captives and their age could not be perfectly determined.

The cats have a rete mirabile in the skull base and they do not have a large extracranial ICA, but, into the cranium, this vessel divides in branches similar to the human being. The MCA of cats is relatively ease to be approached and temporary or permanent occluded $^{7,11}$, but the used approaches had the disadvantages of being mutilating, causing loss of vision and great extent of cranial resection allowing brain herniation. Berkelbach Van der Sprenkel and Tulleken $^{7}$, in 1986, proposed a postorbital microsurgical approach in order to minimize these problems, and to simulate situations found during intracranial neurovascular procedures performed in human beings.

Function impairment or morphological lesion can occur when there is a decrease in the blood flow to the brain bellow a threshold by a critical period of time $^{12}$. Nevertheless, development of ischemic infarct or selective necrosis depends not only on the severity of the ischemic shock, but also on the biochemical changes started during the ischemic period and during the early stage of reperfusion ${ }^{13}$. Such biochemical changes seen to be especially important in the temporary ischemia with active reperfusion, where, under specifics circumstances, the delayed neuronal death that primarily survive the ischemic period may occur $^{14,15}$.

Based on the acquired knowledge several studies with drugs such as magnesium and antioxidants ${ }^{16}$, barbiturates ${ }^{8,17}$, manitol ${ }^{1}$, ketamine ${ }^{18}$ and ketoprofen ${ }^{19}$ have been performed in an attempt to minimize the harmful effect of ischemia, aiming to offer protection to brain tissue. Besides studies using drugs, the neuroprotective effect of mild/moderated hypothermia during transient cerebral ischemia has been well established during the last decade $e^{4,8,20,21}$.

Schaller and $\mathrm{Graf}^{3}$, reviewed the pathophysiological background for the neuroprotective effect of hypothermia on stroke and the main findings were: decrease in the synthesis, release and recovery of neurotransmitters, specially the extracellular glutamate, reduction of postischemic changes in cerebral perfusion, decrease of the blood-brain barrier permeability, reduction in the brain metabolic rate, in the release of free radicals, and in the intracellular acidosis; resynthesis of ubiquitin; inhibition of protein kinases, and recuperation of the synthesis of proteins ${ }^{4,15,20-25}$. According to Huh et al. ${ }^{20}$, the mechanisms of injury improved by mild/moderated 
hypothermia were: release of excitatory neurotransmitters; activation of the protein kinases; decrease of brain-barrier permeability; production of oxygen radical with peroxidative damage to the lipids, protein or deoxyribonucleic acid; change in gene expression; ischemic depolarizations; cytoskeletal breakdown, microglial activation, and reduction in the brain metabolic rate.

We did not find studies on neuroprotection with hypothermia in transient focal ischemia in cats in the reviewed literature. In this paper we looked for put the convenience of the experimental model of temporary focal cerebral ischemia in cats together with the search for neuroprotective effect of mild hypothermia in these animals.

Occlusion of the MCA in cats caused a variable infarct area in the territory supplied by this vessel, extending from the basal ganglia to the surface of the parietal lobe, as reported in previous studies ${ }^{7,11}$. Our results showed that the regions compromised by the ischemic process were similar in the two experimental groups, and the lesions predominated in the olfactory and motor cortex and in the basal ganglia.

In our study, hypothermia had a significant neuroprotective effect in the temporary focal ischemia in brain cats. Some animals of the group under hypothermia do not presented area of ischemia, and this was not observed in animal under normothermia. Besides of this, in the animals presenting ischemic lesions, the areas of the lesions were smaller when under hypothermia than under normothermia.

Administration of barbiturates in burst-suppressive doses is considered the current gold standard for neuroprotection ${ }^{4}$. We did not perform electroencephalographic registration to verify if the doses of barbiturate used were enough for burst suppression. Therefore, a contribution of the barbiturates for the observed neuroprotective effect cannot be excluded but, even if this happened, it affected the two experimental groups because barbiturates were used in the same way for animals of both groups. Besides of this, Westermaier et al. ${ }^{8}$, demonstrated that no additional neuroprotection was observed using barbiturates in burst-suppressive doses in rats submitted to focal temporary cerebral ischemia under mild/moderated hypothermia. In the same way, a neuroprotective effect has been attributed to the ketamine ${ }^{17,18}$, and this could contribute to the neuroprotective effect observed in our animals, but, as for barbiturates, they were used similarly for both experimental groups.
The observation of animals that do not presented ischemic lesions in the group of animals under hypothermia and animals with small and extensive lesions in animals of both experimental groups suggest that, as is observed in the human being, cats present individual variability in the response to the ischemic phenomenon by temporary occlusion of a great vessel (MCA), probably because some animals had previous developed functional collateral circulation. Possibly, the age of the animal also contributed for these observations. This variability observed in both groups also suggests that it do not depend on the neuroprotection maneuvers.

As pointed out by some authors ${ }^{2,26}$, experimental evidence and clinical experience has shown that hypothermia protects the brain from damage during ischemia due to stroke. There is also a growing feeling that hypothermia may be a therapeutic option for the treatment of stroke. Nevertheless, despite its obvious therapeutic potential, hypothermia has not been well investigated as a form of neuroprotection for human stroke. Because of the small number of patients in the clinical studies and the absence of matched controls, they are considered pilot studies for feasibility and safety. Therefore, hypothermia as therapeutic modality for ischemic stroke remains promising but very controversial ${ }^{26}$, and multicentric controlled randomized clinical trials are needed for clarifying this problem.

In conclusion, mild hypothermia did not interfere in the localization of the ischemia (cortical areas and basal ganglia), but it was effective for reducing of the volume of cerebral ischemia in cats submitted to temporary occlusion of the MCA.

\section{REFERENCES}

1. Ogilvy CS, Chu D, Kaplan S. Mild hypothermia, hypertension, and mannitol are protective against infarction during experimental intracranial temporary vessel occlusion. Neurosurgery 1993;38:1202-1210.

2. Olsen TS, Weber UJ, Kammersgaard LP. Therapeutic hypothermia for acute stroke. Lancet Neurol 2003;2:410-416.

3. Schaller B, Graf R. Hypothermia and stroke: the pathophysiological background. Pathophysiology 2002;10:7-35.

4. Barone FC, Feuerstein GZ, White RT. Brain cooling during transient focal ischemia provides complete neuroprotection. Neurosci Behav Rev 1997;21:31-44.

5. Goto Y, Kassel NF, Hiramatsu K, Soleau SW, Lee KS. Effects of intraischemic hypothermia on cerebral damage in a model of reversible focal ischemia. Neurosurgery 1993;32:980-985.

6. Nakano H. Efeito da hipotermia leve nas lesões da isquemia cerebral temporária com reperfusão em gatos. Tese. Ribeirão Preto, 2006.

7. Berkelbach Van Der Sprenkel JW, Tulleken CAF. The postorbital approach to the middle cerebral artery in cats. Stroke 1988;19:503-506.

8. Westermaier T, Zausinger S, Baethmann A, Steiger H, Schimid-Elsaesser R. No additional neuroprotection provided by barbiturate-induced suppression under mild hypothermic conditions in rats subjected to reversible focal ischemia. J Neurosurg 2000;93:835-844.

9. Avendaño C, Roda JM, Carceller F, Diez-Tejedor E. Morphometric study 
of focal cerebral ischemia in rats: a stereological evaluation. Brain Res 1995;673:83-92.

10. Reinoso-Suárez F. Topographischer Hirnatlas der Katze für Experimental - Physiologische Untersuchungen. Darmstadt: E. Merck, A.G., 1961.

11. O'Brien MD, Waltz AG. Transorbital approach for occluding the middle cerebral artery without craniectomy. Stroke 1973;4:201-206.

12. Heiss WD, Rosner G. Functional recovery of cortical neurons as related to degree and duration of ischemia. Ann Neurol 1989;14:294-301.

13. Siesjo BK. Cell damage in the brain: a speculative synthesis. J Cer Blood Flow Metab 1981;1:155-185.

14. Kirino T. Delayed neuronal death in the gerbil hippocampus following ischemia. Brain Res 1982; 239: 57-69.

15. Yamashita K, Eguchi Y, Kajiwara K, Ito H. Mild hypothermia ameliorates ubiqutitin synthesis and prevents delayed neuronal death in the gerbil hyppocampus. Stroke 1991;22:1574-1581.

16. Schmid-Elsaesser R, Hungerhuber E, Zausinger S, Baethmann A, Reulen H. Combination drug therapy and mild hypothermia: a promising treatment strategy for reversible focal cerebral ischemia. Stroke 1999; 30:1891-1899.

17. Cheng MA, Theard MA, Tempelhoff, R. Intravenous agents and intraoperative neuroprotection: beyond barbiturates. Crit Care Clin 1997; 13:185-199.

18. Proescholdt M, Heimann A, Kempski O. Neuroprotection of S(+) ketamine isomer in global forebrain ischemia. Brain Res 2001;904:245-251.
19. Dias LAA, Colli BO, Coutinho J Netto, Lachat JJ. Avaliação da isquemia cerebral focal induzida pela oclusão da artéria cerebral média e a ação neuroprotetora do cetoprofeno em ratos. Arq Neuropsiquiatr 2000; 58:1047-1054.

20. Huh PW, Belayev L, Zhao W, Koch S, Busto R, Ginsberg MD. Comparative neuroprotective efficacy of prolonged moderate intraischemic and postischemic hypothermia in focal cerebral ischemia. J Neurosurg 2000; 92:91-99.

21. Toyoda T. Suzuki S, Kassel NF, Lee KS. Intraischemic hypothermia attenuates neutrophil infiltration in the rat neocortex after focal ischemiareperfusion injury. Neurosurgery 1996;39:1200-1205.

22. Morecai Y, Globus MY, Busto R, et al. Intra-ischemic extracellular release of dopamine and glutamate is associated with striatal vulnerability to ischemia. Neurosci Lett 1992;91:36-40.

23. Karibe H, Chen J, Zarow GJ, Graham SH, Weintein PR. Delayed induction of mild hypothermia to reduce infarct volume after temporary middle cerebral artery occlusion in rats. J Neurosurg 1994;80:112-119.

24. Cobertt D, Hamilton M, Colbourne F. Persistent neuroprotection with prolonged postischemic hypothermia in adult rats subjected to transient middle cerebral artery occlusion. Exp Neurol 2000;163:200-206.

25. Ginsberg MD, Sternau LL, Globus MY, Dietrich WD, Bust R. Therapeutic modulation of brain temperature: relevance to ischemic brain injury. Cerebrovasc Brain Metab Rev 1992;4:189-225.

26. Kontas AA, Choi JH, Pile-Spellman J. Neuroprotection for ischemic stroke using hypothermia. Neurocrit Care 2006;4:168-178. 